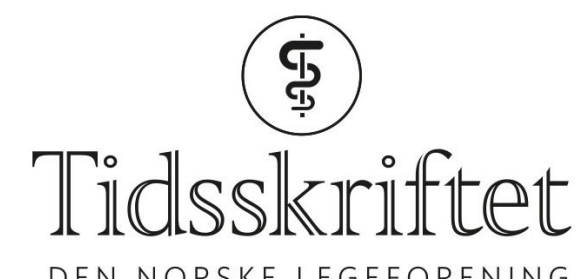

DEN NORSKE LEGEFORENING

\title{
Bølgjer i ei lever
}

MEDISINEN I BILDER

KRISTIAN KOLNES

E-post: kristian.kolnes@gmail.com

Avdeling for radiologi

Volda sjukehus

Kristian Kolnes er spesialist i radiologi og overlege.

Forfattaren har fylt ut ICMJE-skjemaet og oppgir ingen interessekonfliktar.

\section{THOMAS KLEINRATH}

Avdeling for radiologi

Volda sjukehus

Thomas Kleinrath er spesialist i radiologi og seksjonsoverlege.

Forfattaren har fylt ut ICMJE-skjemaet og oppgir ingen interessekonfliktar.

\section{NAOHISA KAMIYAMA}

GE Healthcare

Tokyo, Japan

Naohisa Kamiyama er m.sc., ph.d. og global manager.

Forfattaren har fylt ut ICMJE-skjemaet og oppgir ingen interessekonfliktar.

Bilete og video viser eit iaugefallande fenomen som kan oppstå i levra ved ultralyd med kontrastmiddel. Ein mann var tilvist til kontrastforsterka ultralydrettleia biopsi av ein mistenkt metastase i levra. Etter biopseringa vart levra skanna med konvensjonell gråtoneundersøking (høg akustisk energi). Då oppstod ei ekkorik/lys bølgje som tilsynelatande rulla fram og tilbake gjennom levervevet. Likskapen med nordlys var slåande.

Kontrastvæska som vert gitt intravenøst inneheld tallrike gassbobler med storleik om lag som blodlekamar. Boblene sirkulerer i blodet og gir auka ekko frå vevet. Metastasar vil oftast vere mørke. Dels grunna energien frå ultralydbølgjene vil boblene etter kvart breste, og då oppstår kortvarig høgt ekko. Eit ultralydprogram med låg akustisk energi vert nytta for å forseinke bobleknusinga.

Fenomenet er beskrive tidlegare (1). Den ekkorike bølgja representerer pågåande knusing av bobler på grunn av høg akustisk energi. Dette skjer i grensa mellom ventrale del, som er ekkofattig og der dei fleste boblene allereie er knuste, og dorsale del, som er ekkorik og der færre bobler er knuste. Bølgja fer tilsynelatande fram og tilbake fordi ein beveger ultralydproben og pasienten pustar. Dessutan beveger bølgja seg langsomt i dorsal retning under den kontinuerlege bobleknusinga. Vi nytta kontrastvæska Sonazoid. Boblene i dette kontrastmiddelet er robuste mot akustisk trykk, og toler fleire ultralydsveip før dei sprekk. Bølgjene oppstår ikkje ved skanning med låg energi, men inntreffer rett etter skifte til høg energi. Dette har vi seinare reprodusert gjentekne gongar og hos ulike pasientar. 
Fenomenet er ein artefakt og har inga klinisk betydning, men er nyttig å kjenne til for alle som praktiserer kontrastforsterka ultralyd med Sonazoid.

\section{LITTERATUR:}

1. Edey AJ, Ryan SM, Beese RC et al. Ultrasound imaging of liver metastases in the delayed parenchymal phase following administration of Sonazoid using a destructive mode technique (Agent Detection Imaging). Clin Radiol 2008; 63: 1112-20. [PubMed][CrossRef]

Publisert: 18. november 2019. Tidsskr Nor Legeforen. DOI: 10.4045/tidsskr.19.0136 Mottatt 12.2.2019, første revisjon innsendt 13.7.2019, godkjent 20.9.2019.

(C) Tidsskrift for Den norske legeforening 2020. Lastet ned fra tidsskriftet.no 